\title{
WHY DO LOW- AND HIGH-SKILL WORKERS MigRATE? \\ FLOW EVIDENCE FROM FRANCE
}

\author{
DOMINIQUE M. GROSS
}

NICOLAS SCHMITT

\author{
CESIFO WORKING PAPER NO. 1797 \\ CATEgORY 7: TRAdE POLICY \\ SEPTEMBER 2006
}

An electronic version of the paper may be downloaded

- from the SSRN website:

- from the RePEc website:

- from the CESifo website:

www.SSRN.com

www.RePEc.org

www.CESifo-group.de 


\title{
WHY DO LOW- AND HIGH-SKILL WORKERS MigRATE? \\ FLOW EVIDENCE FROM FRANCE
}

\begin{abstract}
With a focus on the role of cultural clustering and income distribution, this paper investigates whether standard determinants influence international migration of workers to France with the same intensity across different skill levels and with or without free mobility. We find that low-skill migrants respond to most push and pull migration factors. High-skill migrants however respond only to financial incentives and cultural clustering does not matter. Migration policy is effective at controlling flows of low-skill migrants but free mobility has no impact on high-skill flows. Hence, France must rely on growing earnings and skillpremium to attract high-skill workers from high income countries.
\end{abstract}

JEL Code: F22, J24, O24.

Dominique M. Gross

Simon Fraser University

Graduate Public Policy Program

Harbour Centre

515 West Hastings St.

Vancouver BC V6B 5K3

Canada
Nicolas Schmitt

Simon Fraser University

Department of Economics

8888 University Drive

Burnaby BC V5A $1 S 6$

Canada

schmitt@sfu.ca

August 2006

We thank Brigitte van Baalen, Vangheli Lakiotis and Florence Miguet from the University of Geneva for their very helpful research assistance. Financial support from SSHRC-INE program is gratefully acknowledged. 


\section{Introduction}

In this paper, we investigate what economic factors drive international migration of workers and how they vary across different skill levels. We also evaluate whether free mobility does influence incentives to migrate. In particular, we analyze whether free mobility is able to affect the skill mix of migration flows, or whether selective relaxation of constraints on migration of high skill workers is more effective. Specifically, we attempt to answer the following questions: (1) Do the factors that traditionally affect overall international migration flows vary in intensity across skill categories? (2) Does free mobility change workers' incentives to move and if so, is it different for low- and high-skill workers?

To address these questions we expand to the multi-skill case the immigration flow model from Gross and Schmitt (2003) that links labor-market opportunities for new immigrant workers to cultural network and apply it to France. After identifying the factors that drive low- and high-skill migration, we test for the impact of free mobility between high income countries. We also make the distinction between developing/transition source-countries and high-income countries without freemobility agreements. France is used as the test case for the empirical investigation for at least two reasons. First the specifics of immigration policy allow for the isolation of worker flows from other types of migrant flows (family reunion, refugees, etc.) and within that category statistics distinguish between three skill-related categories of occupations. Second, as a member of the EU, France has had free-mobility agreements with its main neighbors for decades yet, since the mid-1990s like many other high-income countries it has started to relax some of the constraints on the entry of high-skill labor from other countries. Simultaneously, constraints on low-skill workers have not changed or have even been tightened. 
The empirical analysis covers low- and high-skill worker flows to France from 67 countries between 1983 and 2000. We show the most standard migration drivers found in the literature to affect overall migration flows, such as relative income at home and destination and the presence of cultural networks, also drive low-skill flows whether they come from high-income or developing countries. High-skill workers, however, are solely influenced by income perspectives at destination, i.e., the standard of living in France. Notably, career prospects matter only for those coming from high-income source countries suggesting that high-skill workers from developing/transition economies value other non-measured benefits such as health care and education. Finally and perhaps surprisingly, free mobility among high-income countries has had very limited impact on any skill category. Hence, a strong conclusion emerging from this study is that, with global competition, attracting high-skill individuals requires more than simply relaxing immigration constraints partially or fully.

Concerns about the effect of globalization on movements of people has recently fed worries in many Western governments about what appears to be growing pressures from large flows of lowskill people and the simultaneous difficulties in attracting high-skill individuals. It is therefore important to better understand what drives skill-specific immigration flows. Yet very little in the literature has been devoted specifically to that issue theoretically or empirically. ${ }^{1}$ One reason is the scarcity of precise data on the international flows of migrants. In particular, main immigration countries, like the US or Canada, do not link skill selection to job contracts for permanent immigrants. Canada for example has a sophisticated system of skill selection but it is becoming increasingly clear that many high-skill immigrants do not find jobs in occupations they have been trained for (see for example Reitz, 2000).

\footnotetext{
${ }^{1}$ The international economics literature has addressed indirectly related issues such as the possible substitution or complementarity between trade and migration flows (see Harris and Schmitt, 2003, for a survey), the relationship between brain drain and development (see for example, Bhagwati and Wilson, 1989), and more recently the role of remittances (see for example, Faini, 2006). A simple model of two-way migration by skill levels is presented by Schmitt and Soubeyran (2006).
} 
The most relevant stream of studies for our purpose is the one on migration flows anchored in the standard models of individual decision to move. ${ }^{2}$ For example, Clark et al. (2002), and Hatton and Williamson (2002) and, Karemera et al. (2000) look at the role of migration policy on overall migration flows to Canada and the US; Mayda (2005) extends Clark et al.'s work to OECD countries. Gross and Schmitt (2003) focus on cultural clusters as entry points into the labor market for migrants to OECD countries. To our knowledge, however, the flow literature has yet to address the question of migration drivers for different skill categories.

Among the factors that have been shown to affect incentives to migrate significantly at the aggregate level within various empirical frameworks, are financial returns such as relative income and inequality (see for example, Borjas, 1987, 1990, Helliwell, 1997, Hatton and Williamson, 2002). Network effects have also been subject to special scrutiny in the migration context as they are seen as alleviating migration costs (Bartel, 1989, Zimmermann, 1996) or improving employment and/or wage opportunities for newcomers (Gross and Schmitt, 2003). ${ }^{3}$ Note that Izyumov et. al. (2002) find a negative relationship between education level and cultural concentration in international migrant communities in the US and the literature on internal resettlement by immigrants has considered skill differences when analyzing the role of cultural communities in the decision process (see for examples Bartel and Koch, 1991, Newbold, 1999).

Hence, the value-added of this paper is to integrate the main migration drivers in a model for skill-differentiated international migration flows and to evaluate the impact of free mobility on flows compared to marginal relaxation of constraints.

The paper is organized as follows. Section 2 provides some background information on French immigration policy and flows since the mid-1980s. Section 3 develops the theoretical

\footnotetext{
${ }^{2}$ See for example Massey et al. (1993) for a survey of the main demographic and economic factors that drive migration. ${ }^{3}$ High skill migrants are often willing to migrate because of some specific characteristics of the home job market such as institutional or traditional rigidities (Becker et. al., 2003) or, if trained abroad, potential employers' lack of information on the nature of their degree (Kwok and Leland, 1982).
} 
framework and Section 4 describes the empirical implementation and the results. Section 5 offers some concluding comments on possible policy action.

\section{Immigration to France: Data and Policy}

Immigration policy in France is anchored into the Code des Nationalités from 1945 and some aspects are also defined at the European Union level. ${ }^{4}$ New permanent immigrant workers enter the French labor market under two distinct categories: First workers may be recruited abroad in which case employers filing the request for visa must prove that no national can fill the position; second, foreigners who reside legally in France with a job contract but no work permit can file a request for such a permit. The initial permanent work permit is for a minimum period of one year, renewable for successive 10-year periods.

There are exceptions to the above process. From 1947 until 1986, citizens from Algeria were considered "nationals" in France and therefore enjoyed complete freedom of movement between the two countries. Citizens of countries from the European Union (EU), and the European Economic Area (EEA) are also exempted from requesting work permits; their employers, however, had to declare them to the authorities until 2000. One of the corner stones of the Treaty of Rome (1957) is guaranteed free mobility to all citizens from member countries within the European Community (EC) without discrimination after a transition period which ended in 1968 for most founding members (France, Belgium, Netherlands, Luxemburg, Germany, Italy) and in 1972 for UK, Ireland and Denmark. ${ }^{5}$ Greece became a member of the EC in 1981 and free mobility with the rest of the EC became effective in 1988. That year, Portugal and Spain joined the Community and free mobility with the other members became effective on January 1, 1992, at the same time as the 1992-

\footnotetext{
${ }^{4}$ See Blanc-Chaléard (2001) and Weil (1991) for more details.

${ }^{5}$ EEC (1997), art. 48.1. See Gross and Schmitt (2006) for a detailed description of EC free mobility policy during the period and all the references to the official EC documents.
} 
single market agreement which created the European Union (EU). The European Economic Area (EEA) also created in 1992 and regrouping Austria, Finland, Iceland, Liechtenstein, Norway and Sweden instituted free mobility between EEA and EU countries in $1994 .^{6}$

One of the key characteristics of French immigration policy is that it has never involved explicit national quotas on permanent immigrants ${ }^{7}$ and migration flows have evolved mostly under political or economic impulses until 1983, when the implementation of policy regulations was tightened, requirements for work permits were redefined and strictly enforced. Yearly flow of new permanent immigrant workers became conditioned on the state of the labor market (Blanc-Chaléard, 2001, Chapter 5, Section 3). Since then, no major change of policy for immigrant workers has occurred, except that, since the 1990s, some emphasis has been put on attracting highly skilled foreigners. ${ }^{8}$ Taking advantage of the stability of the immigration policy framework this study covers the period 1983 to 2000 . The end year is determined by the fact that workers from EU countries are no longer registered after 2000.

Permanent immigrant workers are individuals who have a job contract for more than 12 months and who obtain a work permit for the first time. Taking into account the fact that 1992 is an atypical year, ${ }^{9}$ from 1983, the proportion of permanent workers in total immigrant inflow rose steadily at the expense of family reunion to reach $43 \%$ in 1994 (see Figure 1). In the second part of the 1990s, a partial amnesty for family members in 1997 and a stubbornly high unemployment rate (around 12\%) which may have stimulated the hiring of temporary rather than permanent foreign workers are likely to be responsible for the drop in the share of permanent workers to about $28 \%$ in 1998.

\footnotetext{
${ }^{6}$ See EEC (1994), Appendix V, pp. 0325-0326. In 1995, Austria, Finland and Sweden became members of the Union and their accession had no new implications for mobility.

7 There are however quotas on special categories such as seasonal workers and young professionals in training.

${ }^{8}$ Specifically, some categories of high-skill workers, such as senior executives, highly-trained technicians of foreign multinationals, and researchers became exempted from the labor market condition (OECD, 1998, p.106).

${ }^{9}$ In 1992 there was a marked rise due to Spain and Portugal accession to free mobility within the EU. For example, from 768 permanent workers in 1991, the flow from Portugal rose to 15,221 in 1992; in 1993, it fell back to 7,512.
} 


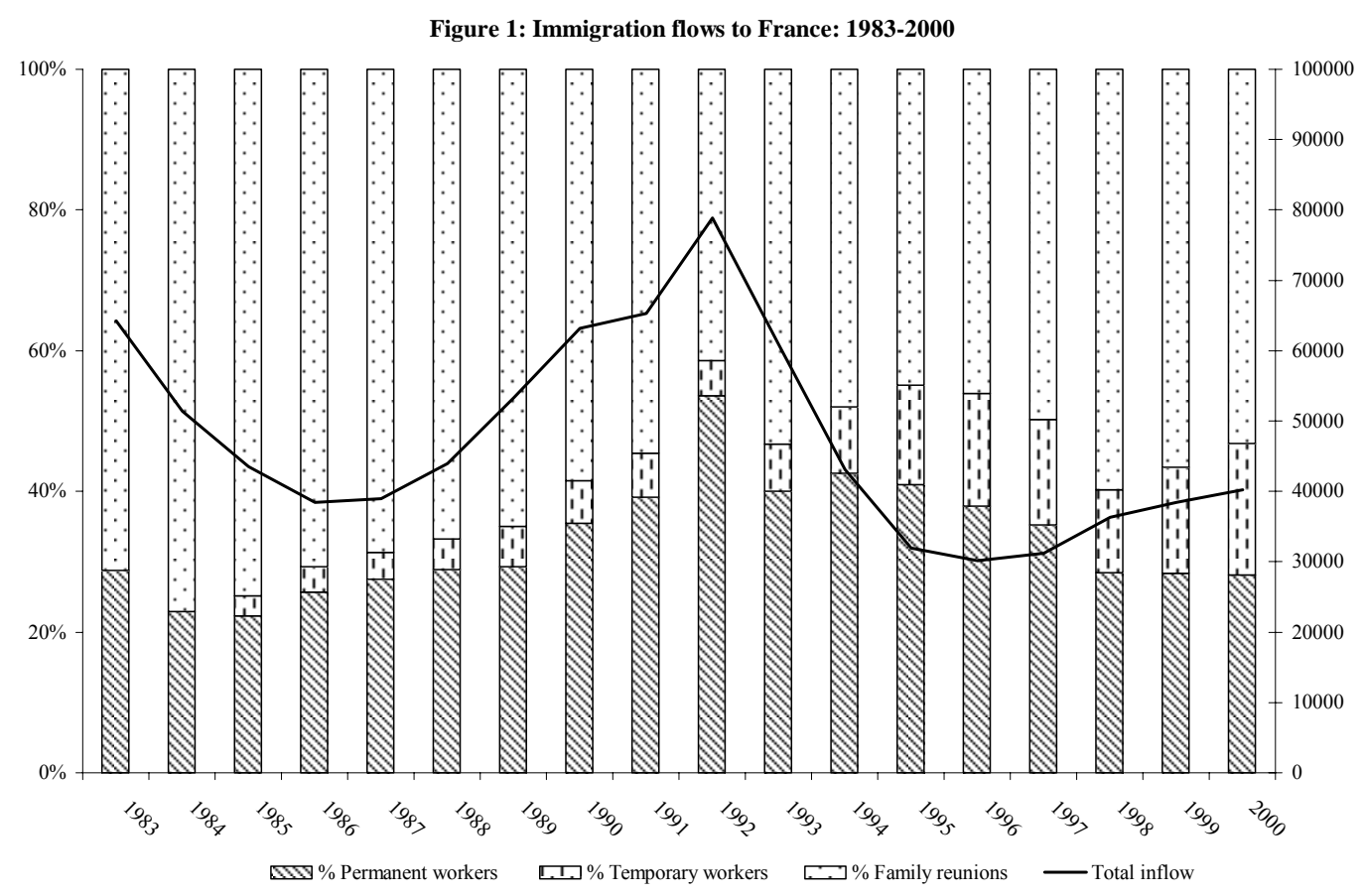

Figure 2: Distribution by skill categories

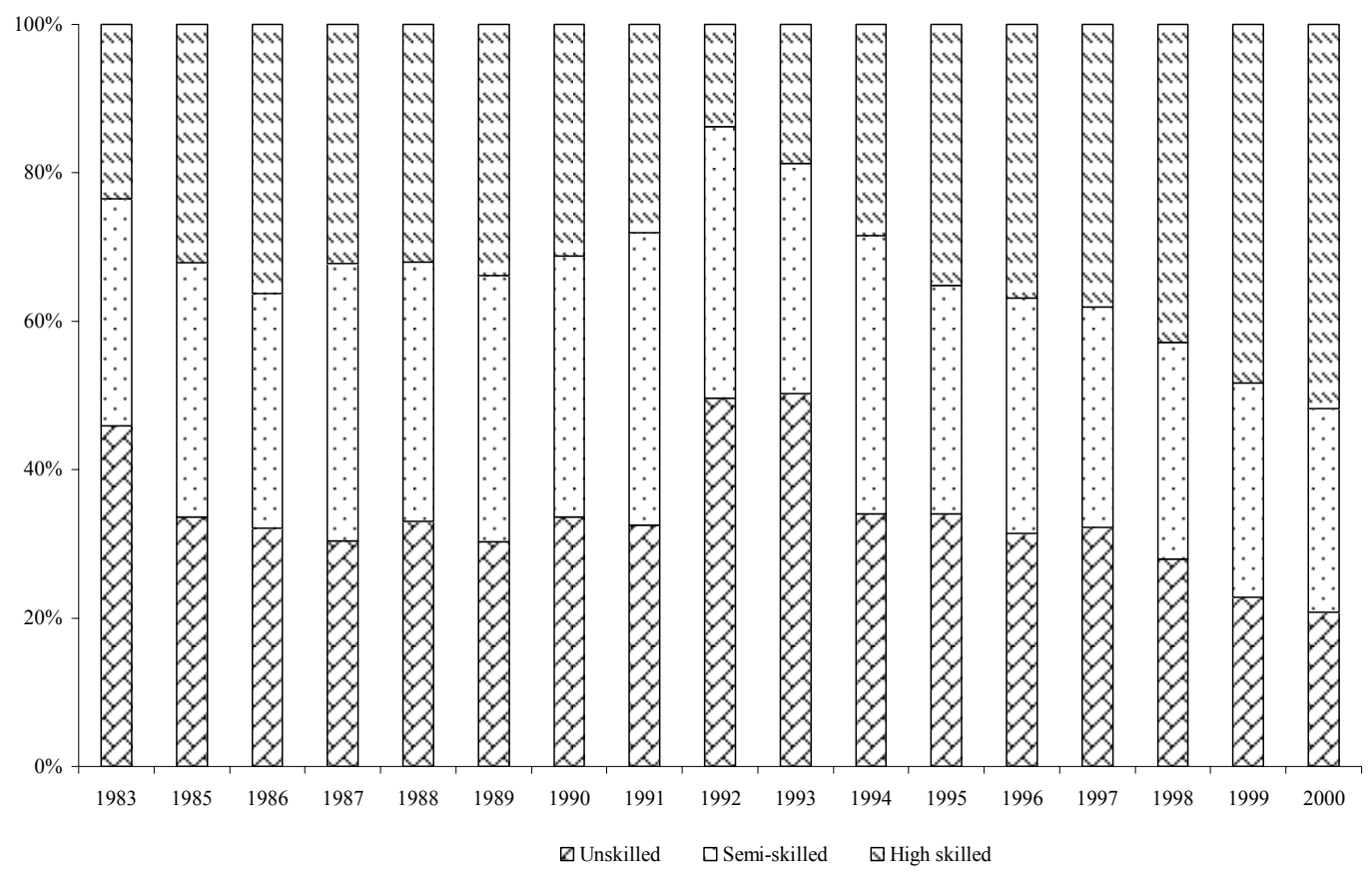

Figure 2 shows the evolution of the skill composition of permanent immigrant workers (also called immigrants or migrants thereafter). There have been some significant changes since the 
mid-1980s with, in particular a complete reversal in the proportions of low- and high-skill migrants. ${ }^{10}$ In the mid 1980 s, they were $42 \%$ and $26 \%$ respectively and in $1998-2000$, they were 23.5\% and 48\%. Abstracting from 1992 when unusually large flow of low-skill Portuguese workers crowded out high-skill workers (14\% of total in 1992), the trend is clearly in favor of high-skill workers as their immigration became more independent of labor market conditions and free mobility within EU involved an increasing number of countries.

Turning to the origin of the permanent workers, the 63 sample source countries cover on average $91 \%$ of all immigrant workers to France $(86.8 \%$ of low skill, and $95.4 \%$ of high skill) between 1983 and 2000. Table 1 provides an overview of their geographical distribution. About 2/3 of all immigrant workers are from high-income OECD countries (including Israel) and their distribution is slightly skewed toward high skill (35\% vs. $32 \%$ on average). Middle East and North Africa (MENA) is the second main source of migration with a slightly lower proportion of highskill migrants (29\%) than high-income countries. Each of the remaining regions represents less than $10 \%$ of all immigrant workers with a general bias toward low skill except Latin America and South East Asia.

Some additional points are worth making. First, the largest total flows are from France's immediate neighbors with free-mobility agreements (Great Britain, Italy, Germany, and Belgium). Second, country-specific skill distributions can be wide and, in all regions, the largest contributor also exhibits the lowest share of high skill (e.g., within high-income OECD countries, 2\% for Portugal; within Sub-Sahara Africa, 8\% for Togo). Third, the US represents the largest high-skill flow and skill intensity $(10,108$ or $89.2 \%)$. It is also the country with the highest total flows among those with no free-mobility agreement. Immigrant workers from Japan and Canada also show high-

\footnotetext{
${ }^{10}$ High-skill workers are managers, intellectuals, and technicians which roughly correspond to university education and low-skill workers are unskilled and specialized workers. In this paper we analyze only the two extreme categories of skills. The mid-skill category, made of professional and qualified blue collar workers and qualified employees, remained constant around 1/3 throughout the period. It is analyzed in depth in Gross and Schmitt (2006).
} 
skill intensity but for significantly smaller flows $(5,367$ and 2,305 or $84 \%$ and $82 \%)$. Fourth, SubSahara Africa (SSA), Central Europe-Central Asia (CECA) and East Asia Pacific (EAP) are the regions sending the highest proportion of low-skill workers. However, at the country level, these regions also exhibit very high dispersions and some of them show a very high proportion of highskill workers (67\% for South Africa and 63\% for Hungary).

Table 1: Immigration from Main Countries and regions by skill category (1983-2000)

\begin{tabular}{|c|c|c|c|c|c|c|c|}
\hline & \multirow[b]{2}{*}{$\begin{array}{c}\text { Total } \\
\text { Immigrant } \\
\text { Workers }\end{array}$} & \multirow[b]{2}{*}{$\begin{array}{c}\text { Regional } \\
\text { distribution } \\
\text { (\% of total) }\end{array}$} & \multirow[b]{2}{*}{$\begin{array}{c}\text { Countries } \\
\text { with largest } \\
\text { contribution }^{\mathrm{a}}\end{array}$} & \multicolumn{4}{|c|}{ Skill distribution within regions ${ }^{b}$} \\
\hline & & & & $\begin{array}{c}\text { Low } \\
\text { skill } \\
\text { workers }\end{array}$ & $\begin{array}{c}\text { High } \\
\text { skill } \\
\text { workers }\end{array}$ & $\begin{array}{c}\text { Countries with } \\
\text { highest share of } \\
\text { high skill }\end{array}$ & $\begin{array}{c}\text { Countries with } \\
\text { lowest share of } \\
\text { high skill }\end{array}$ \\
\hline TOTAL & 261,761 & $100 \%$ & - & $\begin{array}{r}91,316 \\
(35 \%)\end{array}$ & $\begin{array}{l}81,208 \\
(31 \%)\end{array}$ & - & - \\
\hline $\begin{array}{l}\text { High Income } \\
\text { and OECD } \\
\text { (HIOECD) }\end{array}$ & 173,394 & $66.2 \%$ & $\begin{array}{c}\text { Portugal, Great } \\
\text { Britain, Italy, } \\
\text { Germany, } \\
\text { Belgium, US }\end{array}$ & $\begin{array}{l}54,691 \\
(32 \%)\end{array}$ & $\begin{array}{l}60,296 \\
(35 \%)\end{array}$ & $\begin{array}{c}\text { US }(89 \%) \\
\text { Japan }(84 \%) \\
\text { Canada }(82 \%)\end{array}$ & $\begin{array}{c}\text { Portugal }(2 \%) \\
\text { Italy }(24 \%) \\
\text { Denmark }(27 \%)\end{array}$ \\
\hline $\begin{array}{l}\text { Middle East } \\
\text { and North } \\
\text { Africa } \\
\text { (MENA) }\end{array}$ & 39,564 & $15.1 \%$ & $\begin{array}{l}\text { Lebanon } \\
\text { Morocco } \\
\text { Algeria }^{c}\end{array}$ & $\begin{array}{r}13,277 \\
(34 \%)\end{array}$ & $\begin{array}{l}11,614 \\
(29 \%)\end{array}$ & $\begin{array}{c}\text { Syria }(46 \%) \\
\text { Egypt }(46 \%) \\
\text { Iran }(42 \%)\end{array}$ & $\begin{array}{c}\text { Lebanon }(22 \%) \\
\text { Morocco }(31 \%) \\
\text { Tunisia }(33 \%)\end{array}$ \\
\hline $\begin{array}{l}\text { Central } \\
\text { Europe and } \\
\text { Central Asia } \\
(\mathrm{CECA}) \\
\end{array}$ & 18,241 & $7.0 \%$ & $\begin{array}{l}\text { Poland } \\
\text { Turkey }\end{array}$ & $\begin{array}{l}9,301 \\
(51 \%)\end{array}$ & $\begin{array}{l}2,727 \\
(15 \%)\end{array}$ & $\begin{array}{l}\text { Hungary }(63 \%) \\
\text { Czechosl.(54\%) } \\
\text { Bulgaria }(45 \%)\end{array}$ & $\begin{array}{l}\text { Turkey }(8 \%) \\
\text { Poland (9\%) }\end{array}$ \\
\hline $\begin{array}{l}\text { Sub Sahara } \\
\text { Africa (SSA) }\end{array}$ & 16,579 & $6.3 \%$ & $\begin{array}{c}\text { Togo } \\
\text { Senegal } \\
\text { Mali }\end{array}$ & $\begin{array}{l}7,977 \\
(48 \%)\end{array}$ & $\begin{array}{l}3,021 \\
(18 \%)\end{array}$ & $\begin{array}{l}\text { South Af. }(67 \%) \\
\text { Madagas. }(42 \%) \\
\text { Cameroon }(41 \%)\end{array}$ & $\begin{array}{c}\text { Guinea }(2 \%) \\
\text { Mali }(7 \%) \\
\text { Togo }(8 \%)\end{array}$ \\
\hline $\begin{array}{l}\text { East Asia } \\
\text { Pacific (EAP) }\end{array}$ & 8,895 & $3.4 \%$ & $\begin{array}{c}\text { China+Taiwan } \\
\text { Cambodia } \\
\text { Lao PDR }\end{array}$ & $\begin{array}{l}4,237 \\
(48 \%)\end{array}$ & $\begin{array}{l}1,768 \\
(20 \%)\end{array}$ & $\begin{array}{l}\text { Thailand }(34 \%) \\
\text { China+T }(34 \%)\end{array}$ & $\begin{array}{l}\text { Lao PDR }(1 \%) \\
\text { Cambodia }(1 \%)\end{array}$ \\
\hline $\begin{array}{l}\text { Latin } \\
\text { America } \\
\text { (LAM) }\end{array}$ & 3,326 & $1.3 \%$ & Brazil & $\begin{array}{l}1,225 \\
(37 \%)\end{array}$ & $\begin{array}{l}1,190 \\
(36 \%)\end{array}$ & $\begin{array}{c}\text { Mexico }(61 \%) \\
\text { Argentina }(57 \%)\end{array}$ & Brazil (27\%) \\
\hline $\begin{array}{l}\text { South Asia } \\
\text { (SA) }\end{array}$ & 1,762 & $0.7 \%$ & - & $\begin{array}{c}608 \\
(35 \%)\end{array}$ & $\begin{array}{c}592 \\
(34 \%)\end{array}$ & India $(46 \%)$ & Pakistan (9\%) \\
\hline
\end{tabular}

${ }^{a}$ At least 1,000 immigrants except for HIOECD where the benchmark is $10,000 .{ }^{b}$ The table shows only the two extreme categories out of three. The mid-skill category is made of qualified and professional workers. ${ }^{\mathrm{c}}$ Immigration from Algeria was not recorded from 1983 to 1985.

Thus, even though Europe is the major source of migration to France, no region can be identified as a strong provider of a skill type. Each region has strong contributing countries to high- 
skill or low-skill flows. Such diversity suggests that migration drivers act with skill-specific intensity and that the role of immigration policy should be investigated in more depth.

\section{Theoretical framework}

Observed migration flows are the result of individuals' decisions to move to a new country and of policy constraints imposed by receiving countries. Models of migration flows are anchored in the traditional push and pull set-up (see for example, Clark et.al, 2002 and Hatton and Williamson, 2002) and our starting point is that individual incentives are skill-specific and freer international mobility may affect these incentives differently. Thus, while factors influencing migration decisions may be the same across skill levels, elasticities or even signs may differ.

The probability that an individual will move from a country to another depends on the comparison of earnings in both location and on migration costs. For an individual $i$ with skill level $s_{i}$ who contemplates migrating to a destination country $d$, the gross gain from migrating is $w^{d}\left(s_{i}\right)$ $w^{o}\left(s_{i}\right)$, where $w^{o}\left(w^{d}\right)$ is the wage in the country of origin (destination). Naturally, wage increases with skills $\left(w^{\prime}\left(s_{i}\right)>0\right)$. If the costs of migrating are denoted by $C$, the probability of migrating can be written as $q=q\left[w^{d}\left(s_{i}\right)-w^{o}\left(s_{i}\right), C\right]$.

While earnings in the country of origin are exogenous, earnings in the country of destination has three main components and can be implicitly written as

$$
w^{d}\left(s_{i}\right)=g\left[\mu^{d}, \phi^{d}\left(s_{i}-\bar{s}\right), s c^{d}\left(s_{i}\right)\right]
$$

Following Borjas et.al. (1992) and, Hunt and Mueller (2004), $w^{d}\left(s_{i}\right)$ depends on the wage distribution in country $d$ represented by the mean (or wage per capita, $\mu^{d}$ ) and the variance which is a function of the parameter $\phi^{d}$ and the mean skill level $\bar{s}$. Assuming that the distribution of skills is the same across countries (destination and origin) but not the returns to these skills, a migrant chooses the destination country where the return to skill is highest. Consequently, everything else 
being constant, a migrant chooses a destination country with a disperse wage distribution when skills are above average $\left(s_{i}>\bar{s}\right)$ and a destination country with a narrow wage distribution when skills are lower than average $\left(s_{i}<\bar{s}\right)$.

The third component, $s c^{d}\left(s_{i}\right)$, represents the premium associated with cultural clustering in the destination country. We show that this premium may strongly depend on skills. Clustering by ethnic origin rests on the assumption that new migrants often face segmented labor markets in destination countries ${ }^{11}$ with a wage different from the one earned in the large anonymous countrywide labor market. Thus, the skill-specific wage in destination country, $w^{d}\left(s_{i}\right)$, can take two values: $w_{a}\left(s_{i}\right)$, the wage in the large labor sub-market, or $w_{e}\left(s_{i}\right)$, the wage in the small ethnic-specific labor sub-market. ${ }^{12}$ Wages are assumed to be more sensitive to skills in the large anonymous market than in the small ethnic one $\left(w_{a}^{\prime}\left(s_{i}\right)>w_{e}^{\prime}\left(s_{i}\right)>0\right)$; that is, high-skill labor has more opportunities in the anonymous than in the small labor market. We show that, up to some upper level $\bar{s}, w_{e}\left(s_{i}\right) \geq w_{a}\left(s_{i}\right)$ may hold in equilibrium. Hence, there is a positive premium, $s c\left(s_{i}\right)$, associated with the small-ethnic labor market. In this case, relatively low skill migrants $\left(s_{i}<\bar{s}\right)$ have an added advantage in clustering culturally in the destination country while those with relatively high skill $\left(s_{i} \geq \bar{s}\right)$ have no such advantage.

Two characteristics are needed for cultural clustering to occur: Specific cultural job attributes, which naturally generate a segmentation of the market, and higher quality of information within the small labor sub-market. The basic model is a repeated game with imperfect information between a small group of $n$ employers in the small ethnic labor market and migrant workers who must choose whether to supply a high $\left(e_{h}\right)$ or a low level of unobservable effort $\left(e_{l}\right)$ (see Gross and Schmitt, 2003 for details).

\footnotetext{
${ }^{11}$ For example, relatively small labor markets for migrants of close ethnic backgrounds may depend on specific cultural knowledge or language.

${ }^{12}$ From now on, we disregard superscript $d$.
} 
In this model, a high effort in the small labor market is supplied provided that $\left(w_{e}\left(s_{i}\right)-e_{h}\right)\left(1+\delta+\delta^{2}+\ldots\right)>\left(w_{e}\left(s_{i}\right)-e_{l}\right)+\left[p(n)\left(w_{e}\left(s_{i}\right)-e_{l}\right)+(1-p(n))\left(w_{a}-e_{l}\right)\right]\left(\delta+\delta^{2}+\ldots\right)$

where $\delta$ is the migrant's discount factor, assumed to be uniformly distributed over the support $[0,1]$ and for any skill level. The term on the left-hand side of the above inequality is the present value of the migrant's payoff when choosing a high level of effort in every period, and the right-hand side represents the migrant's payoff given today's choice of a low level of effort and the probability $p(n)$ of finding another high-paying job in subsequent periods. ${ }^{13}$ It is composed of the migrant's instantaneous payoff from shirking (the first term) and of the present value of the expected payoff from finding a new job (in the small or in the large labor market) in every subsequent period after having shirked. Earning a high wage without providing a high level of effort is feasible but it represents only a short-term advantage. Indeed, the cost of 'shirking' comes from losing the current job once a low level of output is observed. A high level of effort is supplied only when the migrant cares sufficiently about the future. This can be seen by rewriting the above inequality as

$$
\delta>\delta^{*}\left(s_{i}\right)=\frac{e_{h}-e_{l}}{[1-p(n)]\left[w_{e}\left(s_{i}\right)-w_{a}\left(s_{i}\right)\right]}
$$

In $(2), \delta^{*}\left(s_{i}\right)$ is the critical discount factor above which a new migrant with skill $s_{i}$ chooses a high level of effort and below which she chooses a low level of effort. Since the discount rate is uniformly distributed over the support [0,1] among the new migrants for each skill level, (2) also gives the proportion of migrants for each skill level that are shirking.

There are two important points about (2). First, the larger the small labor market, the higher the proportion of shirkers among migrants $\left(\delta^{*}\left(s_{i}\right)\right.$ increases with $p(n)$ since $\left.p^{\prime}(n)>0\right)$ forcing employers in these labor markets to lower posted wages. Second, the critical rate depends on skills.

\footnotetext{
${ }^{13}$ This probability depends on the quality of the information on this market which depends on the number of employers, $n$. Thus the larger $n$ is, the less informed employers are and the higher is the probability of finding a high paying job after having shirked in previous periods.
} 
Since $w_{a}^{\prime}\left(s_{i}\right)>w_{e}^{\prime}\left(s_{i}\right)>0,\left[w_{e}\left(s_{i}\right)-w_{a}\left(s_{i}\right)\right]$ decreases when $s_{i}$ increases. As a result, $\delta^{*}\left(s_{i}\right)$ rises and the share of shirkers increases with skills. Employers in the small labor market are thus less likely to offer a wage with a premium to individuals with high skills with respect to the wage in the anonymous labor market. In other words, high-skill workers have less incentive to cluster culturally than low-skill workers.

So far we have disregarded migration costs. Aside from the usual monetary costs of migration linked to distance, immigration policies which regulate entries of applicants influence the probability to migrate. Since France has free mobility within the European Union and a restrictive policy with other countries, we model the change from restricted to free mobility as a reduction in the direct fixed cost of migrating, $C$, assuming that this fixed cost is independent of skills (see Clark et al., 2002). The introduction of free mobility should thus have a direct but differentiated positive effect on the flows of migrants. In particular, the reduction of this fixed cost has a stronger effect on the flows of low-skill migrants than on the flows of high-skill migrants.

The above description relates to an individual's probability to migrate to a particular country and needs to be adapted to the more aggregate framework of migration flows. From now on, we reinterpret $i$ as indexing a class of skills and no longer the skill of an individual. Hence the number of individuals belonging to a class of skill deciding to migrate from a given county to some destination is the product of individual probability and the size of the relevant population such that,

$$
\operatorname{Mig}\left(s_{i}\right)=q^{i}\left[w^{o}\left(s_{i}\right), \mu^{d}, \phi\left(s_{i}-\bar{s}\right), s c^{d}\left(s_{i}\right), C\right] \times \operatorname{pop}\left(s_{i}\right) .
$$

We now turn to the estimation of the flow equation including the factors from (3).

\section{Estimation and Results}

The estimation framework is a fixed effect model such that, 


$$
\begin{aligned}
& y_{j, t}^{i}=\alpha+X \beta+\mu_{j, t}^{i}, \\
& u_{j, t}^{i}=\mu_{j}^{i}+v_{j, t}^{i} .
\end{aligned}
$$

The inflow of migrant workers for skill category $i$ ( $i=l$ or $h$, low or high skill) from country $j$ during period $t\left(y_{j, t}^{i}\right)$ is a function of the factors in (3) (i.e., matrix $\boldsymbol{X}$ ), an unobservable individual fixed effect for each source-country/France combination for skill level $i\left(\mu_{j}^{i}\right)$, and of an error term with the usual properties $\left(v_{j, t}^{i}\right)$. A log linear approximation for (4) using names for actual measures can be written as,

$$
\begin{aligned}
\operatorname{LIFL}_{j, t}^{i} & =\alpha_{j}^{i}+\beta_{1} \text { LPOP }_{j, t-1}^{i}+\beta_{2} \text { LINC }_{j, t-1}+\beta_{3} \text { LINCF }_{t-1}+\beta_{4} \text { LDIST }_{j, t-1}^{i}+\beta_{5} L_{C U L T} T_{j, t-1} \\
& +\beta_{6} \operatorname{UNEMPF}_{t-1}+\beta_{7} \text { FREEMOB }_{j, t}+\beta_{z} D_{z, t}+v_{j, t}^{i},
\end{aligned}
$$

where, $\alpha_{j}^{i}$ is the source-country specific fixed effect (for example, distance, or policy bias). We estimate separately the model for each skill category and thus, for each case the dataset is made of 63 balanced panels of six 3-year periods that is 378 observations on inflows of skill-specific migrant workers.

The dependent variable, $L I F L_{j, t}^{i}$, is the log of the flow of new workers from source country $j$ to France during period $t$, for a given skill level $i$. To avoid too many zero values and decrease the potential for simultaneity between dependent and independent variables, annual flows are summed over 3 years between 1983 and $2000(t=6) .{ }^{14}$ The means for the two skill specific dependent variables are very close (242 and 215 individuals for low and high skill) but their dispersions are quite different (see Appendix, Table A.1). While the minimum value is 0 for both skill categories, the maximum is 17,579 for low-skill workers and 2,706 for high-skill workers. The much larger maximum in the low-skill category is due to the surge in immigration from Portugal following accession to free mobility in 1992. When it is eliminated from the sample, the maximum is about a

\footnotetext{
${ }^{14}$ The transformation $\ln \left(\right.$ infl $\left._{j, t}^{S}+1\right)$ is applied to the remaining small number of zero-observations ( 9 for low- and 8 for high-skill flows). A detailed description of all variables is provided in the Appendix.
} 
third as high $(5,235)$. The maximum flow for high-skill workers is from the UK in 1989-91 which may be linked to a fourfold increase in foreign direct investment in that period.

Based on our theoretical arguments, matrix $\boldsymbol{X}$ includes the relevant population in source countries $\left(L P O P_{j, t-1}^{i}\right)$ which captures a scale effect for the potential pool of immigrants. Total population is weighted by Barro and Lee (1997, 2000)'s share of people who have completed secondary school for low-skill ${ }^{15}$ and high school for high-skill migrants.

Relative financial incentives are measured by average incomes, i.e., income per capita in the source country and in France $\left(L I N C_{j, t-1}, L I N C F_{t-1}\right)$ and by the skill-specific distribution of income in France relative to source country $\left(L D I S T_{j, t-1}^{i}\right)$. Income per capita varies by a factor of more than 500 between the poorest (Ethiopia, Togo, India) and the richest (Luxembourg, Switzerland, US). The push/pull argument predicts a negative/positive impact on flows from increased income in source/destination country. In addition, following our theoretical argument we expect an increase in relative income variability to increase the flow of high-skill workers (i.e., positive sign) and decrease the flow of low-skill workers (i.e., negative sign). On average, low- and high-skill income dispersions are very close in France and in source countries (in Table A.1., averages of ratios are 1.01 and 0.99). Across sample countries however, the distribution is more concentrated for highskill than for low-skill income (maximum country-specific values are 2.38 vs. 3.98 for similar minima). Also, all countries with dispersions for both skill categories higher than France are developing countries except for Israel. Moreover, extremely large income dispersions for both skill categories are observed in Sub-Sahara Africa and Middle-East North Africa. On average over the years, most high-income countries exhibit lower dispersion than France in both skill categories and, not surprisingly, countries which are the most equal in the two skill categories are Northern European countries such as Denmark and Norway (high- and low-skill income diverge by less than

\footnotetext{
${ }^{15}$ Results for low-skill migration are insensitive to the use of population with completed primary school as the simple correlation between primary and secondary completion rates is 0.904 .
} 
10\% from average). Canada, the US and Australia show higher dispersion for high skill and lower for low skill than France. Because of these large differences among high-income countries, we also test whether it matters that the source country has higher dispersion/lower dispersion than France and thus, even though dispersion is constant for France, ${ }^{16}$ we use the ratio of destination/source country distributions.

The cultural clustering variable is the number of people from the same origin (region or country) already established in France ( $L C U L T_{k, t-1}$ with $\mathrm{k}=1$ to 13). As in Clark et.al. (2002), it is constructed by extrapolating annual values between the results of two consecutive censuses. Unfortunately, data is not available for all source countries individually and, in some cases the variable had to be computed for regions which can be considered culturally homogenous. ${ }^{17}$ Also, we allow for the network factor to carry a different weight for immigrants from countries that are French-speaking in whole or part (Belgium, Canada, Luxemburg and Switzerland) or are a former French colony by interacting a $L A N G U A G E$ dummy with the cultural variable.

Finally we differentiate between two policy regimes: Restricted immigration based on labor market conditions measured by French unemployment rate $\left(U N E M P F_{t-1}\right)$, and free mobility for EU members measured by a dummy which takes value 1 when the agreement is implemented with a given country $\left(F R E E M O B_{j, t}\right)$. Initially, the dummy is used as a shift factor to be consistent with our cost assumption. Then, we test for the impact of change in policy on incentives by interacting the dummy with selected migration determinants. Furthermore, since EU countries are all high-income countries, using a dummy for high-income countries without free-mobility agreement allows for the distinction between developing/transition and high-income countries under similar policy regime.

\footnotetext{
${ }^{16}$ Skill-specific income data for France is available only for one period (1995 to 1997) and is therefore held constant over the sample. Nevertheless Ladaique (2005) shows that variations in relative revenues for the bottom, middle and top quintiles have not changed between the mid-1980s and 2000. A result confirms by no gain or loss in income share for these quintiles from mid-1980s to mid-1990s (OECD, 1997a).

${ }^{17}$ The only exception is America as there is not distinct data for North and South America, however, most immigrants are from North America.
} 
The other policy event taken into account by a dummy is the change of status of Algerian workers for whom free mobility became restricted with the introduction of work permits in 1986 $\left(D_{1}=\right.$ Algeria $)$. Finally, we also control for the war in Lebanon from 1983 to $1989\left(D_{2}=\right.$ Lebanon $)$ which led to a relaxation of immigration rules and much larger than usual flows of migrants.

\subsection{Basic specification}

Starting with the basic specification with free mobility measured by a shift dummy, the two skill categories clearly exhibit vastly different results (Table 2, columns 1 and 5). While most standard migration drivers matter for low-skill workers, only one is clearly significant for high-skill workers. Before discussing the implications of these results we present some tests for robustness. First, we allow for the network factor to carry a different weight for francophone migrants (columns 2 and 6); even though the language advantage is weakly significant (p-value around 0.15) and only for low-skill migrants, we maintain the variable in the specification. Then, we allow for alternative measures of income dispersion and cultural clustering (columns 3, 4 and 7, 8). Dispersion is computed over all income classes (top income over bottom income) and cultural clustering is for broadly defined regions (LCULTREG). Signs and coefficient magnitudes remain stable but none of these alternatives offers markedly improved results. We therefore use specifications in columns 2 and 6 for further discussion.

According to this basic specification, flows of low-skill migrants respond to the predicted impact of most factors (source and destination incomes, cultural clustering). The pool of relevant population is however not significant. This should be expected in a world with controls over immigration. The significance of the policy indicator (i.e., French unemployment rate) with the expected negative sign indicates that it acts as a regulator of the flows of migrant workers. 
Table 2: Flow of immigrant workers: Basic specification

\begin{tabular}{|c|c|c|c|c|c|c|c|c|}
\hline & 1. & 2. & 3. & 4. & 5. & 6. & 7. & 8. \\
\hline & $\operatorname{LIFL}_{i, t}^{i}$ & $\operatorname{LIFL}_{i, t}^{i}$ & $\operatorname{LIFL}_{i, t}^{i}$ & $\operatorname{LIFL}_{i, t}^{i}$ & $\operatorname{LIFL}_{i, t}^{i}$ & $\operatorname{LIFL}_{i, t}^{i}$ & $\operatorname{LIFL}_{i, t}^{i}$ & $\operatorname{LIFL}_{i, t}^{i}$ \\
\hline & \multicolumn{4}{|c|}{ LOW SKILL } & \multicolumn{4}{|c|}{ HIGH SKILL } \\
\hline $\operatorname{LPOP}_{j, t-1}^{i}$ (Skill specific) & $-.314(.358)$ & $-.117(.756)$ & $-.184(.602)$ & $-.106(.778)$ & $-.056(.810)$ & $-.072(.750)$ & $-.027(.904)$ & $-.073(.749)$ \\
\hline$L I N C_{j, t-1}$ & $-1.356(.021)^{* *}$ & $-1.491(.007)^{* *}$ & $-1.613(.002)^{* *}$ & $-1.499(.007)^{* *}$ & $-.167(.693)$ & $-.096(.813)$ & $-.073(.849)$ & $-.100(.805)$ \\
\hline$L I N C F_{t-1}$ & $4.187(.003)^{* *}$ & $4.129(.003)^{* *}$ & $4.574(.001)^{* *}$ & $4.136(.003)^{* *}$ & $3.538(.002)^{* *}$ & $3.430(.003)^{* *}$ & $3.433(.003)^{* *}$ & $3.439(.003)^{* *}$ \\
\hline$U N E M F_{t-1}$ & $-.383(.000)^{* *}$ & $-.382(.000)^{* *}$ & $-.379(.000)^{* *}$ & $-.383(.000)^{* *}$ & $-.027(.216)$ & $-.029(.174)$ & $-.027(.206)$ & $-.029(.170)$ \\
\hline FREEMOB & $3.096(.000)^{* *}$ & $3.203(.000)^{* *}$ & $3.032(.000)^{* *}$ & $3.195(.000)^{* *}$ & $-.160(.431)$ & $-.191(.345)$ & $-.279(.187)$ & $-.195(.340)$ \\
\hline$L C U L T_{k, t-1}$ & $1.042(.059)^{*}$ & $1.532(.026)^{* *}$ & - & $1.510(.027)^{* *}$ & $.069(.821)$ & $-.143(.671)$ & - & $-.153(.644)$ \\
\hline LCULT (French speak.) & - & $-1.367(.146)$ & $-.753(.399)$ & $-1.387(.138)$ & - & $.552(.364)$ & $.826(184)$ & $.552(.365)$ \\
\hline LDIST $_{i, t-1}^{i}$ (Skill specific) & $-.669(.212)$ & $-.576(.262)$ & $-.610(.245)$ & - & $.291(.483)$ & $.234(.579)$ & $.205(.633)$ & - \\
\hline $\begin{array}{l}L^{L D I S T} T_{j, t-1} \text { (Overall) } \\
\text { LCULT (Regions) }\end{array}$ & $\begin{array}{l}- \\
-\end{array}$ & $\begin{array}{l}- \\
-\end{array}$ & $\begin{array}{c}- \\
.882(.179)\end{array}$ & $\begin{array}{c}.338(.316) \\
-\end{array}$ & - & $\begin{array}{l}- \\
-\end{array}$ & $\begin{array}{c}- \\
-.483(.230)\end{array}$ & $\begin{array}{c}.089(.670) \\
-\end{array}$ \\
\hline $\mathbf{T}$ & 6 & 6 & 6 & 6 & 6 & 6 & 6 & 6 \\
\hline $\mathbf{N}$ & 63 & 63 & 63 & 63 & 63 & 63 & 63 & 63 \\
\hline d.f. & 306 & 305 & 305 & 305 & 306 & 305 & 305 & 305 \\
\hline F-test for $\mu^{i}=\mu_{j}^{i}$ & $15.681(.000)$ & $14.418(.000)$ & $13.409(.000)$ & $14.334(.000)$ & $16.807(.000)$ & $13.998(.000)$ & $14.009(.000)$ & $14.155(.000)$ \\
\hline Adj. $\mathbf{R}^{2}$ & .795 & .797 & .792 & .797 & .891 & .891 & .892 & .891 \\
\hline Schwarz B.I.C & 687.0 & 687.8 & 692.2 & 687.9 & 521.9 & 523.9 & 522.6 & 524.0 \\
\hline
\end{tabular}

The estimations include source-country specific fixed effects and a dummy for the war in Lebanon and the change in policy toward Algeria which are not reported here. Standard errors are heteroskedastic-consistent. P-value in parentheses. 
Moreover, the hypothesis of significant source-country fixed effects cannot be rejected (F-test for $\mu^{i}=\mu_{j}^{i}$ ) and it might capture part of the scale effect. ${ }^{18}$ The non-proportionality bias is likely to be further reinforced by the build-up of cultural communities through time which act as a strong driver for new inflows. Finally, free mobility did generate an average increase of approximately $3 \%$ in low-skill migration at time of accession to EU.

The results for the high-skill workers are vastly different as only one factor matters: French per capita income (i.e., standard of living). Cultural network and accession to free mobility do not matter thereby confirming our hypothesis that migration drivers are different for low- and high-skill migration. Furthermore, the policy enforcement indicator (i.e., unemployment rate) is not significant suggesting that general migration restrictions have not much relevance for high-skill worker migration when it is conditioned on a job contract. The results may also reflect the fact that immigration of high-skill workers concerns relocation of executives, researchers and teachers who benefited from a relaxation on constraints on work permits since the mid-1990s (see Section 3). In fact, between 1995 and 2000, the number of intra-company transferees increased by a factor of 2.5 in France (OECD, 2002, Part I, Table I4).

To summarize, the important point uncovered from the basic specification is that low- and high-skill workers do not respond to incentives with the same intensity. In other words, aggregate studies, which tend to find a role for most immigration drivers (Clark et. al., 2002, Gross and Schmitt, 2003) are misleading in explaining high-skill migration.

\subsection{Migration policy and skill-specific migration.}

We now make the distinction between high-income source countries with and without free mobility and between high-income source countries and developing/transition countries without

\footnotetext{
${ }^{18}$ Consistent with our earlier observation that skill distribution is country rather than region specific, an estimation by OLS with regional dummy is obviously biased given the significance of the fixed effect model.
} 
free mobility; to do so we interact the free-mobility dummy and a dummy for high-income countries without free mobility with selected explanatory variables. Because of high correlation among some explanatory variables, ${ }^{19}$ we condition the estimations on identical population and income elasticities across all types of countries and focus on differential effects for the main variables of interest in this study: cultural clustering, distribution of income and, labor market condition.

In Table 3, column 1, the distinction between countries with and without free mobility is made, regardless of their state of development. As expected, for low-skill migrant the elimination of constraining immigration policy translates into a weaker effect of the labor market indicator confirming that policy is restrictive. Next, we introduce the distinction between rich countries with and without free mobility and proceed sequentially for each factor to avoid multicollinearity bias. Column 4 is the preferred specification for low-skill workers for the basis of further discussion (Table 4) as results in column 3 are unstable and inconsistent with all other trials and the specification criteria show that results in column 2 are less satisfactory.

In columns 5 to 8 , the results for high-skill migrants are less definite. Both the distribution of income and the unemployment rates are significant determinants for rich countries whether there is free mobility or not and the diagnostics are very close for both cases. Nevertheless, considering that France has actively lowered constraints on immigration of high-skill workers (i.e., weakened the role of the unemployment policy parameter), we favor column 7 over 8 for further considerations. ${ }^{20}$ This choice is also consistent with the theoretical predictions of Borjas et al. (1992) and Hunt and Mueller (2004) which argue that distribution of income matters for high skill.

\footnotetext{
${ }^{19}$ For example, simple correlation coefficients between income per capita in EU countries with free-mobility agreements and France, as well as population in EU and unemployment in France are above 0.900.

${ }^{20}$ The policy variable is not expected to be significant for high-income countries without free mobility and in fact when both unemployment rate and income distribution are introduced simultaneously in the equation, the significance of unemployment vanishes.
} 
Table 3: Flow of immigrant workers: Expanded specification

\begin{tabular}{|c|c|c|c|c|c|c|c|c|}
\hline & 1. & 2. & 3. & 4. & 5. & 6. & 7. & 8. \\
\hline & $\operatorname{LIFL}_{i, t}^{i}$ & $\operatorname{LIFL}_{i, t}^{i}$ & $\operatorname{LIFL}_{i, t}^{i}$ & $\operatorname{LIFL}_{i, t}^{i}$ & $\operatorname{LIFL}_{i, t}^{i}$ & $\operatorname{LIFL}_{i, t}^{i}$ & $\operatorname{LIFL}_{i, t}^{i}$ & $\operatorname{LIFL}_{i, t}^{i}$ \\
\hline & \multicolumn{4}{|c|}{ LOW SKILL } & \multicolumn{4}{|c|}{ HIGH SKILL } \\
\hline \multicolumn{9}{|c|}{ Developing and transition countries } \\
\hline $\operatorname{LPOP}_{j, t-1}^{i}$ (Skill specific) & $-.009(.982)$ & $-.286(.419)$ & $-.384(.367)$ & $.117(.771)$ & $-.124(.597)$ & $.015(.948)$ & $-.178(.470)$ & $-.178(.491)$ \\
\hline$L I N C_{j, t-1}$ & $\begin{array}{c}-1.494 \\
(.008)^{* *}\end{array}$ & $\begin{array}{c}-1.491 \\
(.007)^{* *}\end{array}$ & $-1.518(.006)^{* *}$ & $-1.499(.011)^{* *}$ & $-.087(.818)$ & $-.098(.805)$ & $-.106(.786)$ & $-.095(.805)$ \\
\hline$L I N C F_{t-1}$ & $3.857(.011)^{* *}$ & $4.083(.003)^{* *}$ & $6.559(.000)^{* *}$ & $3.572(.021)^{* *}$ & $\begin{array}{c}3.682 \\
(.002)^{* *}\end{array}$ & $\begin{array}{c}3.365 \\
(.003)^{* *}\end{array}$ & $\begin{array}{c}3.828 \\
(.001)^{* *}\end{array}$ & $\begin{array}{c}3.877 \\
(.002)^{* *}\end{array}$ \\
\hline$U N E M F_{t-1}$ & $-.450(.000)^{* *}$ & $-.387(.000)^{* *}$ & $-.361(.000)^{* *}$ & $-.491(.000)^{* *}$ & $.010(.712)$ & $-.026(.218)$ & $-.016(.466)$ & $.008(.805)$ \\
\hline$L C U L T_{k, t-1}$ & $2.058(.007)^{* *}$ & $2.458(.025)^{* *}$ & $.091(.906)$ & $2.205(.002)^{* *}$ & $-.508(.229)$ & $-.608(.336)$ & $-.183(.585)$ & $-.322(.421)$ \\
\hline $\begin{array}{l}\text { LCULT }_{k, t-1} \text { (French } \\
\text { speak.) }\end{array}$ & $-1.474(.114)$ & $-1.838(.088)^{*}$ & $-.471(.648)$ & $-1.498(.098)^{*}$ & $.627(.311)$ & $.830(.212)$ & $.538(.387)$ & $.501(.428)$ \\
\hline $\operatorname{LDIST}_{j, t-1}^{i}($ Skill specific) & $-.558(.345)$ & $-.571(.270)$ & $-.548(.426)$ & $-.403(.443)$ & $.045(.920)$ & $.182(.680)$ & $-.162(.737)$ & $.144(.729)$ \\
\hline \multicolumn{9}{|c|}{ High income countries with free mobility(deviation from develop/trans. model) } \\
\hline$U N E M F_{t-1}$ & $.312(.000)^{* *}$ & - & .- & $.400(.000)^{* *}$ & $-.165(.000)^{* *}$ & - & - & $-.106(.038)^{* *}$ \\
\hline$L C U L T_{k, t-1}$ & $-.020(.641)$ & $-1.661(.161)$ & - & - & $.105(.000)^{* *}$ & $.836(.175)$ & - & - \\
\hline $\operatorname{LDIST}_{j, t-1}^{i}($ Skill specific) & $-.955(.212)$ & - & $3.067(.019)^{* *}$ & - & $.397(.446)$ & - & $\begin{array}{l}2.276 \\
(.004)^{* *}\end{array}$ & - \\
\hline \multicolumn{9}{|c|}{ High income countries without free mobility (deviation from develop/trans. model) } \\
\hline$U_{N E M F}{ }_{t-1}$ & - & - & - & $.116(.122)$ & - & - & - & $-.083(.075)^{*}$ \\
\hline$L C U L T_{k, t-1}$ & - & $-1.879(.114)$ & - & - & - & $.845(.171)$ & - & - \\
\hline$L^{2}{ }^{\prime} T_{j, t-1}^{i}$ (Skill specific) & - & - & $-2.929(.081)^{*}$ & - & - & - & $\begin{array}{c}3.054 \\
(.004)^{* *}\end{array}$ & - \\
\hline $\mathbf{T}$ & 6 & 6 & 6 & 6 & 6 & 6 & 6 & 6 \\
\hline $\mathbf{N}$ & 63 & 63 & 63 & 63 & 63 & 63 & 63 & 63 \\
\hline d.f. & 303 & 304 & 304 & 304 & 303 & 304 & 304 & 304 \\
\hline F-test for $\mu^{i}=\mu_{j}^{i}$ & $15.038(.000)$ & $14.257(.000)$ & $12.810(.000)$ & $14.894(.000)$ & $14.154(.000)$ & $13.691(.000)$ & $13.882(.000)$ & $14.150(.000)$ \\
\hline Adj. $R^{2}$ & .804 & .799 & .763 & .805 & .894 & .891 & .893 & .892 \\
\hline Schwarz B.I.C & 686.3 & 687.9 & 719.112 & 682.4 & 523.9 & 525.5 & 533.4 & 523.5 \\
\hline
\end{tabular}

The estimations include source-country specific fixed effects and a dummy for the war in Lebanon and the change in policy toward Algeria which are not reported here.

${ }^{a}$ Standard errors are heteroskedastic-consistent. P-value in parentheses. 
Table 4 reproduces the chosen results in a directly comparable way. Starting with lowskill workers, the elasticity of source income is about $1 / 2$ of that of French income. Hence, standard of living in source countries (developing or transition) must improve about twice as fast to compensate for France's attractiveness. This means that France is generally very attractive to low-skill migrant workers. Note that among the major supplier countries of low-skill workers, only Cambodia and Lao PDR had faster average annual growth rates during the period (5.1\% and $3.1 \%$ vs. $1.2 \%$ for France). Furthermore, changes in inequalities in source countries have no influence.

Table 4: Summary of elasticities

\begin{tabular}{|c|c|c|c|c|}
\hline & $\begin{array}{c}\text { Developing/Transition } \\
\text { countries }\end{array}$ & $\begin{array}{c}\text { High Income } \\
\text { countries }\end{array}$ & $\begin{array}{c}\text { Developing/Transition } \\
\text { countries }\end{array}$ & $\begin{array}{c}\text { High Income } \\
\text { countries }\end{array}$ \\
\hline & \multicolumn{2}{|c|}{$\begin{array}{c}\text { Low Skill } \\
\end{array}$} & \multicolumn{2}{|c|}{$\begin{array}{c}\text { High Skill } \\
\end{array}$} \\
\hline & \multicolumn{4}{|c|}{ Without free mobility } \\
\hline Income source country & -1.50 & -1.50 & $-0.18(\mathrm{~ns})$ & $-0.18(\mathrm{~ns})$ \\
\hline Income en France & 3.57 & 3.57 & 3.83 & 3.83 \\
\hline Job market & -0.49 & -0.09 & $-0.02(\mathrm{~ns})$ & $-0.02(\mathrm{~ns})$ \\
\hline Network & 2.21 & 2.21 & $-0.18(\mathrm{~ns})$ & $-0.18(\mathrm{~ns})$ \\
\hline Network French speaking & 0.71 & 0.71 & $0.36(\mathrm{~ns})$ & $0.36(\mathrm{~ns})$ \\
\hline \multirow[t]{2}{*}{ Income distribution } & $-0.40(\mathrm{~ns})^{\mathrm{a}}$ & $-0.40(\mathrm{~ns})$ & $-0.16(\mathrm{~ns})$ & 2.11 \\
\hline & \multicolumn{4}{|c|}{ With free mobility } \\
\hline Income source country & - & -1.50 & - & $-0.18(\mathrm{~ns})$ \\
\hline Income en France & - & 3.57 & - & 3.83 \\
\hline Job market & - & -0.38 & - & $-0.02(\mathrm{~ns})$ \\
\hline Network & - & 2.21 & - & $-0.18(\mathrm{~ns})$ \\
\hline Network French speaking & - & 0.71 & - & $0.36(\mathrm{~ns})$ \\
\hline Income distribution & - & $-0.40(\mathrm{~ns})$ & - & 2.89 \\
\hline
\end{tabular}

Interestingly, networks matter with the same intensity for all low-skill workers across types of source countries and policies. The only mitigating effect comes from the ability to speak French. Finally, under constraining immigration policy, the job market indicator is much weaker for high income than for developing/transition countries. Remembering that it is the policy indicator for allocation of work permits, this result suggests that there might be a bias toward high-income countries. Moreover, the bias appears to be quite large since under free mobility within EU/EEA, the labor market indicator which now measures job availability, has a larger impact than for high-income countries still under policy. Note however, that since 
immigrants must have a job contract to obtain a work permit the result is likely to reflect a bias in hiring rather than in policy implementation.

Turning to high-skill migrants in the right-hand panel of Table 4 only financial incentives matter. However, only France's per capita income matters for high-skill workers from developing and transition countries, suggesting non-pecuniary benefits such as health care and education quality might be valued rather than higher financial skill-related financial reward. For high-skill workers from high-income countries who are likely to receive comparable nonpecuniary benefits at home, income dispersion as well as standard of living matter regardless of free mobility. ${ }^{21}$ This strong role of financial incentives is indeed not surprising when considering the results of a recent survey of Europeans which shows that "the two strongest motivators of individuals' desire to move to live and work in other countries are wish to improve their pay and income and to enhance their standard of living" (PWC, 2002, p.19-20). Nevertheless France's distribution of high-skill incomes has remained constant for decade implying dispersion in other OECD countries should have decreased for France to be more attractive. Yet there is overwhelming evidence that dispersion in other countries increased. For example, Ladaique (2005) shows that for a majority of OECD members, the upper quintile in the income distribution has become much richer during the period. Hence, in addition to a poor overall growth in per capita income compared to other high-income countries $(1.2 \%$ a year vs. $1.8 \%$ in the Netherlands, $1.7 \%$ in Germany, $1.6 \%$ in Belgium) and the narrowing relative distribution in high incomes indicate that France may have difficulties in attracting high-skill workers from OECD countries. The lowering of immigration constraints for high-skill from non-EU countries combined with no role for income dispersion may then explain its greater success in attracting

\footnotetext{
${ }^{21}$ There is no significant difference in elasticities of income dispersion between countries with larger and countries with smaller income dispersions than France. The p-values for a deviation in coefficient value for countries with a smaller dispersion than France (i.e., DIST $>1$ ) are $0.79,0.42$ and 0.13 for developing/transition countries, high income countries without mobility, and for high-income countries with mobility respectively (results available upon request).
} 
high-skill individuals from developing and transition economies. ${ }^{22}$ Interestingly, France's weak position in the competition for European workers is not new. Already in the 1950s and 1960s the country had difficulties attracting Italian workers who, at the time, were considered the most desirable unskilled workers, but were offered much better working conditions in Germany, Switzerland or the Netherlands (Blanc-Chaléard, 2001, chapter 4, section 3).

Comparing the two categories of skills, a few points raised in this paper have been verified. First, it is clear that cultural clustering matters for low but not for high-skill workers, confirming our theoretical hypothesis that, unlike low-skill, high-skill migrants do not seek a culturally familiar community to ease their transition in the labor market. Hence, the hypothesis that networks act as entry point for the labor market for low-skill workers made in Gross and Schmitt (2003) is verified. It is reinforced by the fact that the knowledge of local language is a sufficient factor to offset some of the need for a familiar cultural community. Second, free mobility is likely to lower migration fixed cost for low-skill workers but has no impact on incentives of either category of workers. However, under constraining policies low-skill workers from high-income countries may benefit from a favorable hiring bias that they lose with free mobility. Third, financial competitiveness is a necessary condition to be successful in attracting high-skill migrant workers from other high-income countries. Specifically, higher income per capita as well as well as a skill-related premium are likely to be more appealing to high-skill workers than free mobility.

\section{Conclusion}

In this paper we analyze whether standard factors deemed to influence migration flows act with the same intensity across skill levels. We find that neither incentive nor policy parameters are similar across skill levels. Most standard migration drivers influence the

\footnotetext{
${ }^{22}$ At the time of the last expansion of free mobility (1992-1994), 10,062 high-skill workers received work permits, $24.2 \%$ were from developing countries. In 1998-2000, out of 14,410 high-skill permits, $41.2 \%$ were for workers from developing countries (see also Gross and Schmitt, 2006).
} 
movement of low-skill workers; only financial incentives matter for high-skill workers. A growing network of compatriots and relative improvement in standard of living can ensure a continuous flow of low-skill migrants. High-skill individuals move according to financial opportunities solely. While increased standard of living and non-pecuniary benefits are attractive enough for high-skill migrants from developing/transition countries, greater skill premia are necessary for those from high-income countries. Finally migration policy is effective at controlling flows of low-skill migrants, yet as formulated in France, they tend to favor migrants from high-income countries. Free mobility or marginal relaxation of migration constraints have however little impact on high-skill flows. Hence, countries which want to compete for the much sought after pool of high-skill workers should consider incentive tools rather than policy tools.

To our knowledge, this study is the first one to deal with skill-specific migration flows. Considering that immigration policy is country-specific, our results cannot be generalized easily, in particular to the so-called traditional immigration countries. Nevertheless, they do match some casual evidence on the behavior of high-skill expatriates. Also, our study is set within the framework of a standard push and pull migration model to allow a direct comparison across the two extreme skill categories. Clearly, the next step is to focus solely on high-skill flows and extend the model and the empirical investigation to the role of high-skill specific factors such as knowledge-intensive clusters or better opportunities for entrepreneurship. 


\section{References}

Bhagwati, J., and J.D. Wilson, 1989. Income Taxation and International Mobility. Cambridge, Ma: MIT Press.

Barro, R.J. and, J.W. Lee, 2000. "International Data on Educational Attainment: Updates and Implications." Center for International Development at Harvard University. Working Paper no 42.

, 1997. "International Measures of Schooling Years and Schooling Quality." American Economic Review. Papers and Proceedings. 86(2). 218-23.

Bartel, A.P., 1989, "Where Do the new U.S. Immigrants Live?" Journal of Labor Economics, 7(4), 371-91.

Bartel, A.P., and M. Koch, 1991, "Intenal Migration of U.S. Immigrants". In J.M. Abowd and R.B. Freeman Eds. Immigration, Trade, and the Labnor Market. Chicago, Ill.: University of Chicago Press. ...

Blanc-Chaléard, Marie-Claude, 2001, Histoire de l'Immigration. Editions La Découverte. Paris.

Becker, S.O., A. Ichino, and G. Peri, 2003, "How Large is the "Brain Drain" from Italy?" Mimeo. CESifo, Munich. March.

Borjas, G.J., 1990, Friends or Strangers: The Impact of Immigrants on the U.S. Economy. (New-York: Basic Books).

, 1987, "Self-Selection and the Earnings of Immigrants." American Economic Review, 77. 531-53.

Borjas, G.J., S.G. Bronars, and S.J. Trejo, 1992, "Self-Selection and Internal Migration in the United States." Journal of Urban Economics. 32. September. 159-182.

Clark, X., Hatton, T.J., and, J.G. Williamson, 2002, "Where do U.S. Immigrants Come from, and Why?” NBER Working Paper \#8998. June.

EEC, European Community, 1997. "Treaty establishing the European Community (Consolidated version). Official Journal. No C340. November 10. Brussells.

, 1994. "Agreement on the European Economic Area." Official Journal. No L001. January 3. Brussels.

Faini, R., 2006. "Remittances and the Brain Drain.” Discussion Paper No 2155. IZA. June.

Gross, D.M., and N. Schmitt, 2006. "Skilled Immigration Flows and Free Mobility in France and Switzerland.” Mimeo. Simon Fraser University. March.

, 2003, "The Role of Cultural Clustering in Attracting New Immigrants." The Journal of Regional Science. 43, 2. 295-318. 
Harris R., and N. Schmitt, 2003. "The Consequences of Increased Labour Mobility within an Integrating North America”. In North American Linkages: Opportunities and Challenges for Canada. Ed. R. Harris. Calgary, Ab: University of Calgary Press. 313-352.

Hatton, T.J., and J.G. Williamson, 2002, "What Fundamentals Drive World Migration?” NBER Paper \#9159.

Helliwell, J.F., 1997, "National Borders, Trade and Migration." Pacific Economic Review, October, 165-85.

Heston, A., R. Summers, and B. Aten, 2002. Penn World Table. Versions 5.6 and 6.1. Center for International Comparisons at the University of Pennsylvania (CICUP). October.

Hunt, G.L., and R.E. Mueller, 2004. "North American Migration: Returns to Skill, Border Effects, and Mobility Costs." The Review of Economics and Statistics. 86,4. 988-1007.

ILO, International Labour Office, 2003a, Yearbook of Labour Statistics. $62^{\text {nd }}$ Issue. Geneva. , 2003b. Key Indicators of the Labour Market. 2001-2002. Geneva.

INSEE, Institut National de la Statistique et des Etudes Economiques, 1999a. «Les Salaires dans les Entreprises en 1998. » INSEE Première. No 687. Décembre. Paris. , 1999b. Recensement de la Population 1999. Paris.

Izyumov, A., N.-T. Chou, P Coomes, and B. Nahata, 2002. "Immigrant Concentration and Educational Attainment: Evidence from US Data." Journal of International Migration and Integration. 3,1. 17-39.

Karemera, D., Oguledo, V.I., and B. Davis, 2000, “A Gravity Model Analysis of International Migration to North America." Applied Economics. 32, 13, 1745-55.

Kwok, V., and H. Leland, 1982, "An Economic Model of the Brain Drain." The American Economic Review. 72, 1, 91-100.

Ladaique M., 2005. "L'Evolution des Inégalités de Revenus en France et dans les Pays OCDE." Revenus des Ménages et Territoires. Division des Politiques Sociales. OECD. Paris.

Massey, D.S., J. Arango, G. Hugo, A. Kouaouci, A. Pellegrino, and J.E. Taylor, 1993, “Theories of International Migrations: A Review and Appraisal." Population and Development Review. 19, 3. 431-66.

Mayda, A.M., 2005, "International Migration: A Panel Data Analysis of Economic and NonEconomic Determinants.” Discussion Paper No 1590. Institute for the Study of Labor, IZA. Bonn. May.

Newbold, K.B. 1999. "Spatial Distribution and Redistribution of the Foreign-Born in the US: 1980-1990.” Economic Geography. 75, 3. 254-71.

OECD, 1997, 1998, 1999, 2001, 2002, Trends in International Migration. Annual Report. Paris. 
, 1997a. "Income Distribution and Poverty in 13 OECD Countries." OECD Economic Studies No 29. II. Paris.

OMI, Office des Migrations Internationales. Annuaire des Migrations. Various years. Paris.

PWC, Price Waterhouse Coopers, 2002. Managing mobility matters - a European perspective.

Reitz, J. G., 2000. "Immigrant Success in the Knowledge Economy: Institutional Change and the Immigrant Experience in Canada, 1970-1995." Center for Industrial Relations and Department of Sociology, University of Toronto, Toronto.

Schmitt, N. and A. Soubeyran, 2006. "A simple model of brain circulation", Journal of International Economics, 69, 296-309.

Zimmermann, K.F., 1996, "European Migration: Push and Pull”, International Regional Science Review, 19, 1\&2, 95-12.

Weil, P., 1991, La France et ses Etrangers. Collection Folio/Actuel. Paris: Gallimard.

World Bank, 2005. World Development Indicators. Electronic Database. Washington D.C.. 


\section{Appendix: Variables and Data sources}

Immigration flows from Taiwan are combined with those from China; data for the Czechoslovakia and Germany have been recreated using weighted averages with population as the weight. High income countries are OECD members, Austria, Belgium, Denmark, Finland, Germany, Greece, Ireland, Italy, Luxembourg, Netherlands, Norway, Portugal, Spain, Sweden, Switzerland, UK, Australia, Canada, Japan, New-Zealand, US, and Israel.

$\boldsymbol{D}_{1}=$ ALGERIA: dummy equal to 1 in first sub-period (1983-85) and 0 otherwise. From 1947 until 1986, Algerian citizens were considered nationals and did not register as immigrants. In September 1986, France reinstated visas for all countries excluding the EU and Switzerland. (Weil, 1991, p. 338-41).

$\boldsymbol{D}_{2}=\mathbf{L E B A N O N}$ : Dummy equal to 1 during the war period, 1983-1989, and 0 otherwise.

FREEMOB: Dummy equal to 1 for EU/EEA countries with free mobility with France and 0 otherwise. It takes the value 1 for the whole period for Belgium, Denmark, Germany, Ireland, Italy, Luxembourg, The Netherlands, and U.K.; from 1988 on for Greece; from 1992 on for Portugal and Spain; and from 1994 for Austria, Finland and Sweden.

LANGUAGE: Dummy equal to 1 if the country is French-speaking in whole or part (Canada and Switzerland; Luxembourg uses French as official language for legislative texts) or a former French colony in Africa and Asia, and 0 , otherwise.

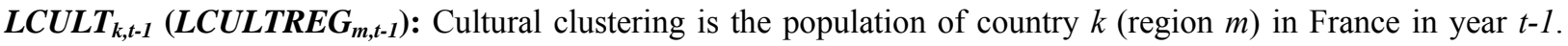
(Weil, 1991; INSEE, 1999b, Table B.02-18). Annual observations are computed by extrapolating observations between three consecutive censuses (March 4, 1982, March 6, 1990 and March 8, 1999) using yearly total inflows of immigrants as in Clark et.al. (2002): $C U L T_{k, t}=\delta C U L T_{k, t-1}+I F L_{k, t-1}^{t o t}$

\begin{tabular}{|c|c|c|}
\hline Country & $\begin{array}{l}\text { Population of same culture } \\
\text { in France } \\
\left(C U L T_{k, t-1}\right)\end{array}$ & $\begin{array}{l}\text { Population of same } \\
\text { region } \\
\left(C U L T R E G_{m, t-1}\right)\end{array}$ \\
\hline $\begin{array}{l}\text { Benin, Burkina Faso, Cameroon, Chad, Congo, } \\
\text { Cote d'Ivoire, Ethiopia, Gabon, Guinea, } \\
\text { Madagascar, Mali, Mauritania, Mauritius, Niger, } \\
\text { Senegal, South Africa, Togo. }\end{array}$ & Sub-Sahara Africa & Sub-Sahara Africa \\
\hline Algeria & Algeria & \multirow{4}{*}{ Maghreb } \\
\hline Tunisia & Tunisia & \\
\hline Morocco & Morocco & \\
\hline Egypt, Lebanon & Maghreb $^{1}$ & \\
\hline Turkey & Turkey & \multirow{3}{*}{ Asia } \\
\hline Vietnam $^{2}$ & Vietnam & \\
\hline $\begin{array}{l}\text { Cambodia, China (incl. Taiwan), India, Iran, Israel, } \\
\text { Japan, Loa PDR, Pakistan, Syria, Thailand }\end{array}$ & $\begin{array}{l}\text { Asia excluding Turkey and } \\
\text { Vietnam }\end{array}$ & \\
\hline Poland & Poland & \multirow[b]{2}{*}{ Europe other than EU } \\
\hline Bulgaria, Czechoslovakia, Hungary, Romania & $\begin{array}{l}\text { Europe other than EU } \\
\text { excluding Poland }\end{array}$ & \\
\hline Argentina, Brazil, Canada, Chile, Mexico, US & America & America \\
\hline $\begin{array}{l}\text { Austria, Belgium, Denmark, Finland, Germany, } \\
\text { Greece, Ireland, Italy, Luxembourg, Netherlands, } \\
\text { Norway, Portugal, Spain, Sweden, Switzerland, UK }\end{array}$ & EU & EU \\
\hline Australia, New-Zealand & Oceania & Oceania \\
\hline
\end{tabular}

LDIST $_{t-1}^{i}$ : Relative distribution of incomes in France and source country $j$ in the previous period. Country-specific indexes for the distribution of incomes are computed as the ratio of the highest income (T) to average (A) for the high skilled and average (A) to bottom (B), for the low skilled based on sectoral income from the ISIC-2Rev decomposition (ILO, 2003a). When a particular year is missing, the closest available year is used. When observations on a sector for several years are missing they are computed from the overall average growth rate. Data is not available for some countries and substitute values are used: For Greece, Portugal is used; for Argentina, the simple average of Brazil and Chile is used; for Cambodia, Loa PDR and Vietnam, the average of China and Myanmar is used; Egypt is used for all Middle East/North Africa countries (Algeria, Iran, Lebanon, Morocco, Syria, 
Tunisia); for Sri Lanka, the average of India and Bangladesh is used. Data for only two countries from Sub-Sahara Africa is available (i.e., Mauritius and Guinea) and information from out of sample countries is used: Kenya for Ethiopia and Madagascar; the average of Guinea and Kenya for Benin, Burkina Faso, Cameroon, Congo, Gabon, Cote d'Ivoire, Senegal and Togo; the average of Egypt and Guinea for Mali, Chad, Niger, Mauritania. Finally, sectoral data for France is not available and net average monthly income for full-time workers in professional categories similar to those for migrant workers is used (i.e., Managers and technicians for top income and unskilled blue-collar workers for bottom income). The only available year is 1997 (INSEE, 1999a).

$\operatorname{LIFL}_{j, t}^{i}$ : Inflow of immigrant workers with $i=l, h$ (low, high skill) from country $j$ (63 source countries) for period $t$ $(\mathrm{t}=1$ to 6; 3-year periods from 1983 to 2000: 1983-85, 1986-88, 1989-91, 1992-94, 1995-97, 1998-2000). Low skill $=$ unskilled and specialised workers; high skill= managers, intellectuals, and technicians. In 1984, the government published only the total number of immigrant workers per skill category. We applied the \% it represents of the average of the two neighboring years (1983 and 1985) to each source country. (OMI).

LINC $_{j, t-1}$ : GDP per capita in constant 2000-US\$ in the last year of the previous period (t-1=1982, 1985, 1988, 1991, 1994, 1997) in source country $j$. (World Bank, 2005). Some early missing values (Guinea, Loa PDR, Vietnam, Lebanon, 1982, 1985 and Czechoslovakia, 1985) have been computed extrapolating from the regional real GDP growth (Heston et.al., 2002).

LINCF $_{t-1}:$ French GDP per capita in constant 2000-US\$ in the last year of the previous period. (World Bank, 2005).

LPOP $_{j, t-1}^{i}$ (SEC/HIGH SCHOOL): 15-64 year old population at the end of the last year of the previous period in source country $j$ multiplied by the share of people aged 25 and over who have completed secondary/high school. (World Bank, 2005, and Barro and Lee, 1997, 2000).

$\boldsymbol{U N E M P F}_{\mathrm{t}-1}$ : Unemployment rate in France in the year preceding each 3-year period (ILO, 2003b).

Table A.1.: Main statistical characteristics of the variables (3-year periods)

\begin{tabular}{|c|c|c|c|}
\hline & Mean & Minimum & Maximum \\
\hline $\begin{array}{l}\text { Inflow immigrant workers }\left(\text { IFL }_{\mathrm{j}, \mathrm{i}}^{\mathrm{i}}\right) \\
\text { low skill (with Portugal) } \\
\text { low skill (without Portugal 1992-94) } \\
\text { high skill }\end{array}$ & $\begin{array}{l}242 \\
215\end{array}$ & $\begin{array}{l}0 \\
0\end{array}$ & $\begin{array}{l}17,579 \\
5,235 \\
2,706\end{array}$ \\
\hline $\begin{array}{l}\text { Population source countries }\left(\mathrm{POP}_{\mathrm{j}, \mathrm{t}-1}^{\mathrm{i}}\right) \text { in millions } \\
\text { Completed secondary school } \\
\text { Completed high school }\end{array}$ & $\begin{array}{l}3.91 \\
1.82\end{array}$ & $\begin{array}{l}0.003 \\
0.003\end{array}$ & $\begin{array}{c}112.6 \\
48.9\end{array}$ \\
\hline Income per capita in source countries $\left(\mathrm{INC}_{\mathrm{j}, \mathrm{t}-1}\right)$ & 8,036 & 85 & $47,820.8$ \\
\hline Income per capita in France $\left(\mathrm{INCF}_{\mathrm{t}-1}\right)$ & 18,393 & 16,243 & 20,292 \\
\hline $\begin{array}{l}\text { Relative distribution of incomes }\left(\mathrm{DIST}_{\mathrm{j}, \mathrm{t}-1}^{\mathrm{i}}\right) \\
\text { low skill dist. }{ }^{\mathrm{a} /} \text { in source countries } \\
\text { low skill dist. in France } \\
\text { ratio for low skill (France/source) }\end{array}$ & $\begin{array}{l}1.54 \\
1.52 \\
0.99\end{array}$ & $\begin{array}{l}1 \\
- \\
1.52\end{array}$ & $\begin{array}{c}3.98 \\
- \\
0.38\end{array}$ \\
\hline $\begin{array}{l}\text { high skill dist. in source countries } \\
\text { high skill dist. in France } \\
\text { ratio for high skill (France/source) }\end{array}$ & $\begin{array}{l}1.48 \\
1.49 \\
1.01\end{array}$ & $\begin{array}{c}1 \\
- \\
1.49\end{array}$ & $\begin{array}{c}2.38 \\
- \\
0.63\end{array}$ \\
\hline Cultural network $\left(\right.$ CULT $\left._{t-1}{ }^{\mathrm{j}}\right)$ in thousands & 519.8 & 1.4 & $1,602.2$ \\
\hline Unemployment rate in France $\left(\mathrm{UNEMPF}_{\mathrm{t}-1}\right)$ & 10.3 & 7.8 & 12.3 \\
\hline
\end{tabular}

a/ distribution is defined as top over average income for high skill and average over bottom for low skill. In both cases, minimum value is 1 and larger value indicate larger dispersion. 


\title{
CESifo Working Paper Series
}

\author{
(for full list see www.cesifo-group.de)
}

1732 Kerstin Bernoth and Guntram B. Wolff, Fool the Markets? Creative Accounting, Fiscal Transparency and Sovereign Risk Premia, May 2006

1733 Emmanuelle Auriol and Pierre M. Picard, Government Outsourcing: Public Contracting with Private Monopoly, May 2006

1734 Guglielmo Maria Caporale and Luis A. Gil-Alana, Modelling Structural Breaks in the US, UK and Japanese Unemployment Rates, May 2006

1735 Emily J. Blanchard, Reevaluating the Role of Trade Agreements: Does Investment Globalization Make the WTO Obsolete?, May 2006

1736 Per Engström and Bertil Holmlund, Tax Evasion and Self-Employment in a High-Tax Country: Evidence from Sweden, May 2006

1737 Erkki Koskela and Mikko Puhakka, Cycles and Indeterminacy in Overlapping Generations Economies with Stone-Geary Preferences, May 2006

1738 Saku Aura and Thomas Davidoff, Supply Constraints and Housing Prices, May 2006

1739 Balázs Égert and Ronald MacDonald, Monetary Transmission Mechanism in Transition Economies: Surveying the Surveyable, June 2006

1740 Ben J. Heijdra and Ward E. Romp, Ageing and Growth in the Small Open Economy, June 2006

1741 Robert Fenge and Volker Meier, Subsidies for Wages and Infrastructure: How to Restrain Undesired Immigration, June 2006

1742 Robert S. Chirinko and Debdulal Mallick, The Elasticity of Derived Demand, Factor Substitution and Product Demand: Corrections to Hicks' Formula and Marshall's Four Rules, June 2006

1743 Harry P. Bowen, Haris Munandar and Jean-Marie Viaene, Evidence and Implications of Zipf's Law for Integrated Economies, June 2006

1744 Markku Lanne and Helmut Luetkepohl, Identifying Monetary Policy Shocks via Changes in Volatility, June 2006

1745 Timo Trimborn, Karl-Josef Koch and Thomas M. Steger, Multi-Dimensional Transitional Dynamics: A Simple Numberical Procedure, June 2006

1746 Vivek H. Dehejia and Yiagadeesen Samy, Labor Standards and Economic Integration in the European Union: An Empirical Analysis, June 2006 
1747 Carlo Altavilla and Paul De Grauwe, Forecasting and Combining Competing Models of Exchange Rate Determination, June 2006

1748 Olaf Posch and Klaus Waelde, Natural Volatility, Welfare and Taxation, June 2006

1749 Christian Holzner, Volker Meier and Martin Werding, Workfare, Monitoring, and Efficiency Wages, June 2006

1750 Steven Brakman, Harry Garretsen and Charles van Marrewijk, Agglomeration and Aid, June 2006

1751 Robert Fenge and Jakob von Weizsäcker, Mixing Bismarck and Child Pension Systems: An Optimum Taxation Approach, June 2006

1752 Helge Berger and Michael Neugart, Labor Courts, Nomination Bias, and Unemployment in Germany, June 2006

1753 Chris van Klaveren, Bernard van Praag and Henriette Maassen van den Brink, A Collective Household Model of Time Allocation - a Comparison of Native Dutch and Immigrant Households in the Netherlands, June 2006

1754 Marko Koethenbuerger, Ex-Post Redistribution in a Federation: Implications for Corrective Policy, July 2006

1755 Axel Dreher, Jan-Egbert Sturm and Heinrich Ursprung, The Impact of Globalization on the Composition of Government Expenditures: Evidence from Panel Data, July 2006

1756 Richard Schmidtke, Private Provision of a Complementary Public Good, July 2006

1757 J. Atsu Amegashie, Intentions and Social Interactions, July 2006

1758 Alessandro Balestrino, Tax Avoidance, Endogenous Social Norms, and the Comparison Income Effect, July 2006

1759 Øystein Thøgersen, Intergenerational Risk Sharing by Means of Pay-as-you-go Programs - an Investigation of Alternative Mechanisms, July 2006

1760 Pascalis Raimondos-Møller and Alan D. Woodland, Steepest Ascent Tariff Reforms, July 2006

1761 Ronald MacDonald and Cezary Wojcik, Catching-up, Inflation Differentials and Credit Booms in a Heterogeneous Monetary Union: Some Implications for EMU and new EU Member States, July 2006

1762 Robert Dur, Status-Seeking in Criminal Subcultures and the Double Dividend of ZeroTolerance, July 2006

1763 Christa Hainz, Business Groups in Emerging Markets - Financial Control and Sequential Investment, July 2006 
1764 Didier Laussel and Raymond Riezman, Fixed Transport Costs and International Trade, July 2006

1765 Rafael Lalive, How do Extended Benefits Affect Unemployment Duration? A Regression Discontinuity Approach, July 2006

1766 Eric Hillebrand, Gunther Schnabl and Yasemin Ulu, Japanese Foreign Exchange Intervention and the Yen/Dollar Exchange Rate: A Simultaneous Equations Approach Using Realized Volatility, July 2006

1767 Carsten Hefeker, EMU Enlargement, Policy Uncertainty and Economic Reforms, July 2006

1768 Giovanni Facchini and Anna Maria Mayda, Individual Attitudes towards Immigrants: Welfare-State Determinants across Countries, July 2006

1769 Maarten Bosker and Harry Garretsen, Geography Rules Too! Economic Development and the Geography of Institutions, July 2006

1770 M. Hashem Pesaran and Allan Timmermann, Testing Dependence among Serially Correlated Multi-category Variables, July 2006

1771 Juergen von Hagen and Haiping Zhang, Financial Liberalization in a Small Open Economy, August 2006

1772 Alessandro Cigno, Is there a Social Security Tax Wedge?, August 2006

1773 Peter Egger, Simon Loretz, Michael Pfaffermayr and Hannes Winner, Corporate Taxation and Multinational Activity, August 2006

1774 Jeremy S.S. Edwards, Wolfgang Eggert and Alfons J. Weichenrieder, The Measurement of Firm Ownership and its Effect on Managerial Pay, August 2006

1775 Scott Alan Carson and Thomas N. Maloney, Living Standards in Black and White: Evidence from the Heights of Ohio Prison Inmates, 1829 - 1913, August 2006

1776 Richard Schmidtke, Two-Sided Markets with Pecuniary and Participation Externalities, August 2006

1777 Ben J. Heijdra and Jenny E. Ligthart, The Transitional Dynamics of Fiscal Policy in Small Open Economies, August 2006

1778 Jay Pil Choi, How Reasonable is the 'Reasonable' Royalty Rate? Damage Rules and Probabilistic Intellectual Property Rights, August 2006

1779 Ludger Woessmann, Efficiency and Equity of European Education and Training Policies, August 2006

1780 Gregory Ponthiere, Growth, Longevity and Public Policy, August 2006 
1781 Laszlo Goerke, Corporate and Personal Income Tax Declarations, August 2006

1782 Florian Englmaier, Pablo Guillén, Loreto Llorente, Sander Onderstal and Rupert Sausgruber, The Chopstick Auction: A Study of the Exposure Problem in Multi-Unit Auctions, August 2006

1783 Adam S. Posen and Daniel Popov Gould, Has EMU had any Impact on the Degree of Wage Restraint?, August 2006

1784 Paolo M. Panteghini, A Simple Explanation for the Unfavorable Tax Treatment of Investment Costs, August 2006

1785 Alan J. Auerbach, Why have Corporate Tax Revenues Declined? Another Look, August 2006

1786 Hideshi Itoh and Hodaka Morita, Formal Contracts, Relational Contracts, and the Holdup Problem, August 2006

1787 Rafael Lalive and Alejandra Cattaneo, Social Interactions and Schooling Decisions, August 2006

1788 George Kapetanios, M. Hashem Pesaran and Takashi Yamagata, Panels with Nonstationary Multifactor Error Structures, August 2006

1789 Torben M. Andersen, Increasing Longevity and Social Security Reforms, August 2006

1790 John Whalley, Recent Regional Agreements: Why so many, why so much Variance in Form, why Coming so fast, and where are they Headed?, August 2006

1791 Sebastian G. Kessing and Kai A. Konrad, Time Consistency and Bureaucratic Budget Competition, August 2006

1792 Bertil Holmlund, Qian Liu and Oskar Nordström Skans, Mind the Gap? Estimating the Effects of Postponing Higher Education, August 2006

1793 Peter Birch Sørensen, Can Capital Income Taxes Survive? And Should They?, August 2006

1794 Michael Kosfeld, Akira Okada and Arno Riedl, Institution Formation in Public Goods Games, September 2006

1795 Marcel Gérard, Reforming the Taxation of Multijurisdictional Enterprises in Europe, a Tentative Appraisal, September 2006

1796 Louis Eeckhoudt, Béatrice Rey and Harris Schlesinger, A Good Sign for Multivariate Risk Taking, September 2006

1797 Dominique M. Gross and Nicolas Schmitt, Why do Low- and High-Skill Workers Migrate? Flow Evidence from France, September 2006 